\title{
Comparative study of continuous lateral osteotomy and microperforating osteotomy in patients undergoing primary rhinoplasty
}

\author{
Diego Sherlon Pizzamiglio', Cezar Augusto Sarraf Berger².
}

\author{
1) Otorhinolaringologist - Medical Hospital IPO. \\ 2) Master in Surgical. Voluntary Professor, Department of Otorhinolaryngology, Federal University of Parana. Otorinolaringologista Medical Hospital IPO. \\ Institution: Hospital IPO \\ Curitiba / PR - Brazil \\ Mailing address: Diego Pizzamiglio - Avenida República Argentina, 2069 - Água Verde -Curitiba / PR - Brazil - Zip code: 80620-010 - E-mail: dpizzamiglio@yahoo.com.br \\ Article received in 23 de março de 2012. Article approved in 22 de maio de 2012.
}

\section{SUMMARY}

Introduction: Lateral osteotomies play an important role in rhinoplasty and can be performed with different techniques. Objective: To compare the results of narrowing of the nasal dorsum and base through 2 types of lateral osteotomy: continuous and microperforating.

Method: We selected 74 patients undergoing rhinoplasty: 37 patients underwent lateral continuous osteotomy and the other 37 underwent microperforating osteotomy, all performed by the same surgeon. We analyzed frontal photography from the preand post-operative (6 months) periods, evaluating the width of the nasal dorsum and base. This was a retrospective study.

Results and Conclusion: Using Student's $t$-test, statistical analysis concluded that there was a statistically significant difference in the post-operative narrowing of the nasal dorsum and base following both osteotomy techniques, and there was no statistically significant difference between the 2 techniques.

Keywords: rhinoplasty, osteotomy, photography.

\section{INTRODUCTION}

As a surgical method used in rhinoplasty, lateral osteotomies have been described and performed according to the surgeon's preferences and training. The main objectives of osteotomies are to narrow the nose, close open roof deformities secondary to deformities originating after nasal hump removal, and to correct nasal asymmetries on the bony pyramid. There is no ideal technique for osteotomies in rhinoplasty, allowing each surgeon to perform it in a different way.

In this study, we aimed to compare the efficiency of lateral osteotomies performed by one surgeon at our hospital in Curitiba, using different techniques to achieve the same objective as a surgical result. Therefore, we evaluated comparisons between the pre- and postoperative pictures of 74 patients from both genders who were divided in to 2 groups of 37 patients each. Patients from the first group underwent rhinoplasty with lateral osteotomy, while patients from the second group underwent rhinoplasty with microperforating osteotomy, both in the period between January 2010 and October 2011. After the study, the results were discussed using statistical analysis of the photographic measurements.

\section{LITERATURE REVIEW}

Rhinoplasty techniques have been described for centuries. Initially, according to Egyptian papyri (1), rhinoplasty aimed to reconstruct nasal soft tissues to correct acquired nasal deformities such as, for example, that of mutilated people. In 1823, the German surgeon DiefFENBACH (2) was the first to perform alterations on the osteocartilaginous nasal dorsum by external incisions. In around 1887, Roe (3) was the first surgeon to describe purely cosmetic nasal surgery. In the $19^{\text {th }}$ century, JosEPH (4) described the first surgical technique to access nasal deformities of the nasal bones.

Lateral osteotomies are rhinoplasty surgical maneuvers that enable the surgeon to narrow the nose, close open roof deformities resulting from hump removal, and correct asymmetry of the nasal bones. They can be performed by continuous technique, creating a single fracture along the lateral portion of the nasal process of the maxilla and nasal bones, or by perforating osteotomy, which creates a series of postage stamp-type perforations along the same line, along the lateral portion of the nasal process of the maxilla and nasal bones. WeBSTER et al. (5) described the "high-low-high" surgical maneuver sequence to lateral osteotomies aimed at preserving the insertion of the head of the inferior turbinate in the pyramid aperture. 
Several lateral osteotomy techniques have been described, but with no consensus about which would be the most effective. The selection of a technique depends on the preferences and individual results of each surgeon. An osteotomy is expected to produce a reliable effect and be reproducible, with minimum trauma to nasal soft tissues, achieving a complete fracture with minimal sequel.

Several studies have compared continuous osteotomies to microperforating osteotomies in terms of edema, post-operative ecchymosis, and osteotome size. These studies verified that there was less edema and ecchymosis in microperforating osteotomies, especially when a smaller, straight osteotome, without guide, of 2 or $3 \mathrm{~mm}$ was used $(6,7,8,9,10,11)$. Tardy and Denneny (6) demonstrated that, when performed with 2-mm osteotomes, lateral microperforating osteotomies cause less ecchymosis and soft tissue trauma compared to continuous osteotomies. Gryskierwicz and Gryskiewicz (7) concluded that microperforation osteotomies using 2-mm osteotomes resulted in less edema and post-operative ecchymosis compared to continuous osteotomies using 4-mm guided osteotomes. Rohrich et al. (8) demonstrated that microperforating osteotomies cause less nasal mucosal damage than continuous osteotomies.

Few studies have demonstrated the effects of lateral osteotomies in rhinoplasty comparing microperforating and continuous techniques. In 2010, Zoumalan et al. (12), through photographic analysis of 60 patients who had undergone rhinoplasty, concluded that both techniques created a statistically significant narrowing of the base of the nose but that there was no statistical difference between both techniques. However, none of the techniques resulted in a statistically significant narrowing of the nasal dorsum. In KortBus et al. (12), photographic study of 20 patients led to the conclusion that lateral osteotomies result in a statistically significant reduction of the base of the nose that does not occur at the dorsum. In that study, a comparison to a group that underwent microperforating osteotomy was not established. Therefore, due to a lack of information in the literature, we decided to compare the techniques applied in our practice to establish the efficacy of these surgical approaches in rhinoplasty.

\section{Method}

The present study was carried out at our hospital (Curitiba Paraná, Brazil), and comprised 74 randomly selected patients from both genders who underwent rhinoplasty with lateral osteotomy to narrow the bone pyramid of the nose. Of these, 37 patients underwent continuous osteotomies, and the other 37 underwent microperforating osteotomies. The same surgeon operated on all patients. The local ethics committee approved the study under approval number $12 / 2010$. All the procedures were performed using local anesthesia and sedation using the basic closed techniques, where all osteotomies were performed via the endonasal route (13). Continuous osteotomies were carried out using a guided 3- or 4-mm curved osteotome, preceded by periosteum displacement, creating a single fracture along the lateral portion of the nasal process of the maxilla and nasal bones. Microperforation fractures were created with a 2- or 3-mm osteotome without guide and without periosteum displacement by making several perforations on the same line orientation, along the lateral portion of the nasal process of the maxilla and nasal bones (Figure 1). All the lateral osteotomies followed the "high-low-high" sequence: beginning at the piriform aperture, above the head of the inferior turbinate (high), extending downwards along the maxilla upward process (low), and ending by ascending $2 \mathrm{~mm}$ before the inner canthus of the eye (high). At the end of the osteotomies, the fractures were completed with a digital compression maneuver. By the end of each rhinoplasty, a dressing was applied on the nasal dorsum using micropore tape and a thermoplastic splint molded over the dorsum of the nose. Nasal packing was not utilized in any of the performed nasal surgeries.

Frontal photographs of all the patients were captured (from a 5-foot distance away from the patients) in the preand post-operative periods, using the same camera, for aesthetic comparison of the surgical procedures. The postoperative photos were obtained 180 days after the surgery to avoid the effect of post-operative edema. In both cases, the comparison was performed by measuring the nasal dorsum width at its wider portion and the nasal bony base at the wider portion of the ascendant maxilla process using photographic analysis of pre-and post-operative images.

To obtain measurements and a possible comparison, the measurement of the wider portion of the nasal dorsum for both the pre- and post-operative images was divided into a fixed parameter in each patient photograph and labeled as the interpupillary distance, minimizing possible errors of distance on the photographs and establishing comparison by means of one ratio measure. The same process was carried out by measuring the bony nasal base at its wider portion of the ascendant process of the maxilla and subsequently dividing it by the interpupillary distance. One researcher made the measurements mentioned above utilizing Adobe Photoshop 5 CS (Figure 2).

The results of the cited ratios, in terms of the variables of the dorsum and base of the nose, were compared considering the pre- and post-operative periods for both groups of patients. The 2 techniques were compared retrospectively by considering the obtained results. 


\section{RESULTS}

Based on the nature of the analyzed data, we proceeded with the statistical approach deemed appropriate. Student's $t$-test was used for statistical analysis of the following measurements:

The relative values of the dorsum and base of the nose before and after the continuous and microperforation techniques, and the differences of the nasal dorsum and base between the continuous and microperforation techniques. The statistical level adopted was $p<0.05$.

Regarding the 37 patients who underwent continuous osteotomies, we obtained statistically significant differences for the pre- and post-operative ratios between the nasal dorsum and interpupillary distance (Table 1), as was also observed for the ratios between the base of the nose and interpupillary distance (Table 2).

Evaluating the 37 patients who underwent rhinoplasty with lateral perforating osteotomies, the preand post-operative ratios between the nasal dorsum distance and interpupillary distance were statistically significant (Table 3), as was the ratio between the distance of the base of the nose and interpupillary distance (Table 4).

Table I. Statistical analysis of the pre- and post-operative measurements of thenasal dorsum with continuous technique.

\begin{tabular}{|c|c|c|c|c|c|}
\hline $\begin{array}{l}\text { Operati- } \\
\text { ve stages }\end{array}$ & $\mathrm{N}$ & $\begin{array}{l}\text { Relative } V a \\
\text { min-max }\end{array}$ & $\begin{array}{l}\text { alue of } \mathrm{Nas} \\
\text { average }\end{array}$ & $\begin{array}{l}\text { alDorsum } \\
\pm s d\end{array}$ & $P$ \\
\hline & 37 & $0.1663-0.2814$ & 0.2383 & \pm 0.0297 & 0.0000 \\
\hline Dost & 37 & $0.1360-0.2698$ & 0.2079 & \pm 0.0279 & \\
\hline
\end{tabular}

Note: N, Number of patients; min-max, minimum and maximum values; sd, standard deviation; p, statistical significance level. Source: The author (2011).

Table 3. Statistical analysis of the pre- and post-operative measurements of thenasal dorsum with perforation technique.

\begin{tabular}{|c|c|c|c|c|c|}
\hline $\begin{array}{l}\text { Operati- } \\
\text { ve stages }\end{array}$ & $N$ & $\begin{array}{l}\text { Relative Valu } \\
\text { min-max }\end{array}$ & $\begin{array}{l}\text { Ie of Nasa } \\
\text { average }\end{array}$ & $\begin{array}{r}\text { Dorsum } \\
\pm \mathrm{sd}\end{array}$ & $p$ \\
\hline re & 37 & $0.1522-0.3005$ & 0.2271 & \pm 0.0392 & 0.002 \\
\hline Post & 37 & $0.1286-0.2739$ & 0.1990 & \pm 0.0345 & \\
\hline
\end{tabular}

Note: N, Number of patients; min-max, minimum and maximum values; sd, standard deviation; $\mathrm{p}$, statistical significance level. Source: The author (2011).

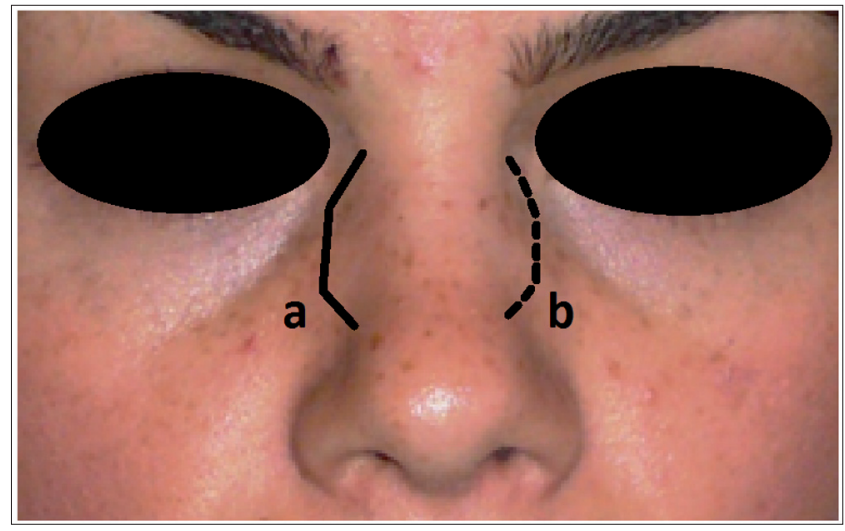

Figure 1. (a) Continuous line indicates continuous osteotomy. (b) Outline depicts microperforating osteotomy.

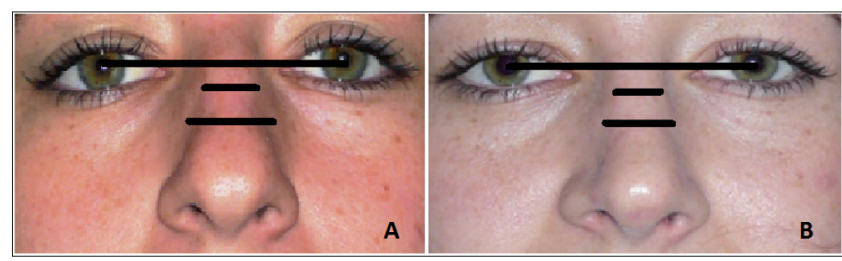

Figure 2. Image A: Pre-operative photograph (left). Image B: Post-operative photograph (right). In both pictures, the top line is the interpupillary line (fixed pre- and post-operative parameter); the inferior line is the nasal base measurement, and the medium line represents the nasal dorsum measurement (variable parameters to be analyzed).

Table 2. Statistical analysis of the pre- and post-operative measurements of the base of thenose with continuous technique.

\begin{tabular}{lllllll}
\hline $\begin{array}{l}\text { Operati- } N \\
\text { ve stages }\end{array}$ & \multicolumn{4}{c}{$\begin{array}{c}\text { Relative Value of Base of the Nose } \\
\text { min-max }\end{array}$} & $P$ \\
\hline Pre & 37 & $0.2462-0.4597$ & 0.3686 & \pm 0.0406 & 0.0000 \\
Post & 37 & $0.2366-0.3936$ & 0.3222 & \pm 0.0341 & \\
\hline
\end{tabular}

Note: $N$, Number of patients; min-max, minimum and maximum values; sd, standard deviation; $\mathrm{p}$, statistical significance level. Source: The author (2011).

Table 4. Statistical analysis of the pre- and post-operative measurements of thebase of thenose with perforation technique.

\begin{tabular}{|c|c|c|c|c|c|}
\hline $\begin{array}{l}\text { Operati- } \\
\text { ve stages }\end{array}$ & $N$ & $\begin{array}{l}\text { Relative Valu } \\
\text { min-max }\end{array}$ & $\begin{array}{l}\text { e of Base } \\
\text { average }\end{array}$ & $\begin{array}{l}\text { ffthe Nose } \\
\pm s d\end{array}$ & $p$ \\
\hline $\begin{array}{l}\text { Pre } \\
\text { Post }\end{array}$ & $\begin{array}{l}37 \\
37\end{array}$ & $\begin{array}{c}0.30-0.5028 \\
0.2697-0.4262\end{array}$ & $\begin{array}{l}0.3824 \\
0.3354\end{array}$ & $\begin{array}{l} \pm 0.0550 \\
\pm 0.0413\end{array}$ & 0.0000 \\
\hline
\end{tabular}

Note: N, Number of patients; min-max, minimum and maximum values; sd, standard deviation; p, statistical significance level. Source: The author (2011). 
Table 5. Statistical analysis of the average difference of the nasal dorsum and the base of the nose between continuous and perforation techniques.

\begin{tabular}{|c|c|c|c|c|c|}
\hline \multirow[t]{2}{*}{ Techniques } & \multirow[t]{2}{*}{$\mathrm{n}$} & \multicolumn{3}{|c|}{ Difference of the Dorsum } & \multirow[t]{2}{*}{$\mathrm{p}$} \\
\hline & & $\min -\max$ & average & $\pm s d$ & \\
\hline $\begin{array}{l}\text { Continuous } \\
\text { Microperforation }\end{array}$ & $\begin{array}{l}37 \\
37\end{array}$ & $\begin{array}{l}-0.006 \text { to } 0.0711 \text { I } \\
-0.0217 \text { to } 0.0754\end{array}$ & $\begin{array}{l}0.0305 \\
0.0281\end{array}$ & $\begin{array}{l} \pm 0.0199 \\
\pm 0.0223 \\
\end{array}$ & 0.63 \\
\hline \multirow[t]{2}{*}{ Techniques } & $n$ & \multicolumn{3}{|c|}{ Difference of the Base } & $p$ \\
\hline & & $\min -\max$ & average & $\pm s d$ & \\
\hline $\begin{array}{l}\text { Continuous } \\
\text { Microperforation }\end{array}$ & $\begin{array}{l}37 \\
37\end{array}$ & $\begin{array}{l}-0.0068 \text { to } 0.1369 \\
-0.0007 \text { to } 0.1408\end{array}$ & $\begin{array}{l}0.0465 \\
0.0470\end{array}$ & $\begin{array}{l} \pm 0.0259 \\
\pm 0.0313\end{array}$ & 0.94 \\
\hline
\end{tabular}

Note: $\mathrm{n}$, Number of patients; min-max, minimum and maximum values; sd, standard deviation; p, statistical significance level. Source: The author (2011).

There were no statistical differences when both osteotomy techniques were compared (Table 5).

\section{DISCUSSION}

In rhinoplasty, several maneuvers, techniques, sutures, and grafts are combined in the same surgery to obtain the best aesthetic and functional result for the patient. The lateral osteotomy is a rhinoplasty surgical technique whose main objective is to narrow the nose and create a harmonious aesthetic effect. There has been discussion regarding the best lateral osteotomy technique, whether the periosteum should be displaced, the stability of the fracture, post-operatory edema, and ecchymosis and tissue damage of the nasal mucosa. It is not possible to reach a consensus regarding what the best option would be; it all depends on surgeon preference and experience. However, some studies in the literature have reported that osteotomies without periosteum displacement have resulted in less post-operative edema and ecchymosis than when the periosteum is displaced, creating less post-operative morbidity because the periosteum and its vascularization remain attached to the bone, providing better nurturing to the healing area.

The majority of the surgeons at our hospital perform rhinoplasty. All of them follow the same surgical precept and surgical steps, from anesthesia to the final nasal dressing, but as expected, each has his own preferences and different appropriations of the technique, which is what propelled us to the development of this work.

Some years ago, in our practice, rhinoplasties were predominant in Caucasian patients; therefore, few alterations in the width of the nasal base were required. However, this profile has changed in recent years; we have observed the miscegenation of our patients and thus observed an ethnic alteration of the noses that required effective osteotomies to obtain nasal narrowing.
The main differences between osteotomies have to do with the post-operative period, when greater edema and ecchymosis are observed following continuous osteotomy in comparison to perforating osteotomy, a fact that can generate more discomfort for the patient and a longer convalescence period. Concerning technique choice, it is the surgeon's duty to decide which to use, since, as we have verified, both techniques are efficient. The surgeon must be comfortable with the elected technique, and be secure with the utilized osteotomes to obtain better results.

\section{CONCLUSION}

The present study verified that there are no statistically significant differences between the results of microperforating and continuous lateral osteotomies, with both being effective at narrowing the nasal dorsum and base. Therefore, we conclude that both techniques deliver a statistically significant narrowing of the nasal dorsum ( $\mathrm{p}$ $<0.05$ ). This is contrary to the data available in the researched literature, in which only the narrowing of the base through both techniques is statistically significant, without mention of the nasal dorsum.

\section{REFERENCES}

1. Brain DJ. The early history of rhinoplasty. Facial Plast Surg, 1993; 9:81-88.

2. Dieffenbach JF. Der Aether gegen den Schmerz.Berlon, Germany: Hirschwald; 1847.

3. Roe JO. The deformity termed "pug nose" and its correction, by a simple operation [reprint published ins Plast Reconstr Surg. 1970, 45:78] Med Rec, 1887; 31:621.

4. Joseph J. Die Hypertrophie der starren Nase: Nasenplastik und sonstige gesichtsplastiküber smammaplastik und einige 
weitere Operationen aus dem gebiete der ausseren Korperplastik. Leipzig, Germany. Kabitzsch: 1931.

5. Webster RC, Davidson TM, Smith RC. Curved lateral osteotomy for airway protection in rhinoplasty. Arch Otolaryngol, 1997; 103:454-8.

6. Trady MEJr, Denneny JC. Micro-osteotomies in rhinoplasty. Facial Plast Surg, 1984; 1:137.

7. Gryskiewicxz JM, Gruskiewicz KM. Nasal osteotomies: a clinical comparison os the perforating mehods versus the continuous technique. Plast Reconstr Surg, 2004; 113(5):1445-58.

8. Rohrich RJ, Minolli JJ, Adams WP, Hollier LH. The lateral nasal osteotomiy in rhinoplasty: an anatominc endoscopic comparison of the external versus the internal approach. Plast Reconstr Surg, 1997; 99(5):1309-12.
9. Kuran I, Ozcan H, Usta A. and Bas L. Comparison of four differente types os osteotomes for lateral osteotomy: A cadaver study. Aesthetic Plast. Surg, 1996; 10:323.

10. Harshbarger RJ and Sullivan PK. Lateral nasal osteotomies: Implications of bony thickness on fracture patterns. Ann. Plast. Surg, 1999; 42:365.

11. Ford CN, Battaglia DG and Gentry IR. Preservation of periosteal attachment in lateral osteotomy. Ann Plast. Surg, 1984; 13:107.

12. Kortbus MJ, Ham J, Fechner F, Constantinides M. Quantitative analysis of lateral osteomomies in rhinoplasty. Arc Facial Plast Surg, 2006; 8(6):369-73.

13. Neto SC, Junior JFM, Martins RHG, Costa SS. Tratado de Otorrinolaringologia e Cirurgia Cervicofacial. Segunda Edição. São Paulo: Editora Roca; 2011, Vol. III, pp. 469-88. 